CASE REPORT

\title{
Two novel mutations of the calcium-sensing receptor gene affecting the same amino acid position lead to opposite phenotypes and reveal the importance of p.N802 on receptor activity
}

\author{
Anne-Sophie Lia-Baldini ${ }^{1}$, Corinne Magdelaine ${ }^{2}$, Angélique Nizou $^{1}$, Coraline Airault $^{1}$, Jean-Pierre Salles ${ }^{3}$, \\ Pierre Moulin ${ }^{3}$, Brigitte Delemer ${ }^{4}$, Mina Aitouares ${ }^{5}$, Benoit Funalot ${ }^{1,2}$, Franck Sturtz ${ }^{1,2}$ and \\ Anne Lienhardt-Roussie ${ }^{6}$ \\ ${ }^{1}$ EA 6309 - Maintenance Myélinique et Neuropathies Périphériques, Faculté de Médecine - Biochimie, Université de Limoges, 6ème étage, 2 rue du Dr \\ Marcland, 87025 Limoges, France, ${ }^{2}$ Laboratoire de Biochimie, Centre Hospitalo-Universitaire de Limoges, Limoges, France, ${ }^{3}$ Unité d'Endocrinologie et des \\ Maladies Osseuses, Centre de références des maladies rares du métabolisme phosphocalcique, Hôpital des Enfants, INSERM Unité 563 (CPTP), Université \\ de Toulouse, Toulouse, France, ${ }^{4}$ Hôpital Robert Debré, CHU de Reims, Service Endocrinologie, Reims, France, ${ }^{5}$ Service de Diabétologie et d’Endocrinologie, \\ Centre Hospitalier, Troyes, France and ${ }^{6}$ Service de Pédiatrie, Centre de référence maladies rares du métabolisme phosphocalcique, \\ Centre Hospitalo-Universitaire Dupuytren, Limoges, France \\ (Correspondence should be addressed to A-S Lia-Baldini; Email: asliabaldini@unilim.fr)
}

\begin{abstract}
Objective: Gain-of-function mutations of the calcium-sensing receptor (CASR) gene have been identified in patients with sporadic or familial autosomal dominant hypocalcemia (ADH). Inactivating mutations of the CASR gene cause familial hypocalciuric hypercalcemia (FHH). Here, we report two novel CASR mutations affecting the same amino acid (p.N802); one causes ADH and the other atypical FHH. Patients and methods: The first patient, an 11-year-old girl suffering from hypocalcemia, developed nephrocalcinosis when she was only 5 years old. The second patient is a 30-year-old woman who presented with mild hypercalcemia. PCR amplification of CASR coding exons and direct sequencing of PCR products were used to identify mutations. Site-directed mutagenesis was used to generate mutated CASR cDNAs in an expression plasmid. Using the MAPK assay system and transient transfection of Cos-7 cells with wild-type (WT) and mutated CASR, we studied the responses of these mutated receptors to extracellular $\mathrm{Ca}^{2+}$ and to the negative allosteric CASR modulator, NPS2143.

Results: Two heterozygous missense mutations (p.N802I and p.N802S) affecting a residue in the sixth transmembrane domain of CASR were identified. In functional tests, the response of the p.N802S mutant to calcium was typical of an inactivating mutation. However, the p.N802I mutant had $70 \%$ of the maximally stimulated WT receptor activity even in the absence of extracellular calcium. This constitutive activity was only partially inhibited by the inhibitor, NPS2143.

Conclusions: The asparagine at amino acid position 802 appears to be essential for the activity of the CASR protein and is implicated in the mechanism of CASR signaling.
\end{abstract}

European Journal of Endocrinology 168 K27-K34

\section{Introduction}

The calcium-sensing receptor (CASR) is a G protein-coupled receptor (GPCR) central to regulating extracellular calcium ion concentrations. CASR is abundant in tissues and cells involved in calcium homeostasis, such as the parathyroid glands and cells lining the kidney tubule (1). It is responsive to very small changes in the circulating calcium concentration and, once activated, it inhibits parathyroid hormone (PTH) secretion and renal tubule calcium reabsorption. The importance of this receptor as a 'calciostat' has been emphasized by the identification of naturally occurring mutations in the CASR gene: inactivating and activating mutations cause hypercalcemic or hypocalcemic disorders respectively $(2,3,4,5)$. Individuals heterozygous for loss-of-function mutations of CASR develop familial hypocalciuric hypercalcemia (FHH) and homozygotes present with neonatal severe hyperparathyroidism (NSHPT). By contrast, familial/sporadic autosomal dominant hypocalcemia $(\mathrm{ADH})$ is caused by heterozygous gainof-function CASR mutations (6). The clinical phenotype of these patients is usually mild or in some cases asymptomatic and the biological phenotype associates hypocalcemia with normal but unadapted persistent calciuria and low PTH levels $(6,7)$. 
More than 131 naturally occurring loss-of-function mutations and 71 gain-of-function mutations have been reported (Fig. 1 and the online database at (http:// www.casrdb.mcgill.ca)) (8). CASR has a large extracellular amino terminal domain (ECD) (606 amino acids corresponding to around $56 \%$ of total amino acids), seven transmembrane domains (TMD) (23\% of protein), and an intracellular carboxy-terminal domain (ICD) ( $21 \%$ of protein). Known loss-of function mutations are scattered throughout the protein, but gain-of-function mutations are nonrandomly distributed (9): $52.1 \%$ map in the ECD (10) and many clusters between residues 116 and 131; 42.3\% map in the TMDs with clusters in TMD6 (23.8\% of TMD mutants) and in TMD7 (30\%); and only $5.6 \%$ are in the ICD (11). The identification and analysis of these naturally occurring mutations have helped elucidate the structure and function of this receptor.

We report a study of two novel mutations, p.N802I and p.N802S, of the CASR gene, affecting the amino acid position 802. This amino acid position is in TMD6 in which seven other mutants have already been described. Intriguingly, the p.N802I and p.N802S mutants behaved differently in functional tests.

\section{Materials and methods}

\section{Patients}

The patients were recruited through the National French Calcium-Phosphorus Network. Informed consent was obtained from the patients and their families, according to the guidelines of the French Bioethics Authority for the protection of human studies.

\section{DNA amplification and sequence analysis}

Genomic DNA was prepared from patient peripheral blood mononuclear cells with an Easy-DNA extraction kit (Invitrogen). Exons 2-7 of the CASR gene, comprising the entire coding sequence, were amplified by PCR. Both strands of the PCR products were sequenced using an Applied Biosystems mode ABI 3130xl automated sequencer with the Big Dye Terminator Cycle Sequencing kit v.1.1 (Applied Biosystems, Foster City, CA, USA).

\section{Site-directed mutagenesis}

The cDNA for human CASR between the HindIII and XhoI restriction sites of the expression vector pCR3.1 (pCR3.1/hCASR) was provided by Prof. Anne LienhardtRoussie (CHU, Limoges, France). The Quick Change Site-Directed Mutagenesis kit (Stratagene, La Jolla, CA, USA) was used according to the manufacturer's directions. The sequence of all constructs was verified by sequencing.

\section{Transient transfection of Cos-7 cells with human CASR cDNA}

Cos-7 cells were propagated in DMEM containing 10\% heat-inactivated FCS (Eurobio, Courtaboeuf, France) in $75 \mathrm{~cm}^{2}$ flasks under $5 \% \mathrm{CO}_{2}$ at $37^{\circ} \mathrm{C}$. For transfection, Cos-7 cells were cultured in six-well plates and transfected with wild-type (WT) or mutant pCR3.1/hCASR DNA and the Elk-1 trans-reporting system (Stratagene) using PolyFect transfection reagents (Qiagen). Twenty-four hours after transfection, cells were starved of serum in DMEM containing no $\mathrm{CaCl}_{2}$ for $8 \mathrm{~h}$ and then cultured for $16 \mathrm{~h}$ in the presence of various concentrations of $\mathrm{CaCl}_{2}$ from 0 to $4 \mathrm{mM}$, with and without $300 \mathrm{nM}$ NPS-2143. Cells were washed in PBS, lysed on ice, and MAPK activity was assayed.

\section{MAPK activity}

Exogenous MAPK activity induced by CASR activation was assessed as described previously (12). In brief, a trans-reporting system (Stratagene) was used to measure the activity of Elk-1, an ETS domain transcription factor targeted by MAPK pathways. Luciferase activity in $25 \mu \mathrm{l}$ aliquots of cell lysate was measured after addition of $50 \mu \mathrm{l}$ D-luciferin using a Turner Biosystems 20/20 ${ }^{\mathrm{n}}$ luminometer (Promega). Luciferase activity was normalized to $\beta$-galactosidase activity.

\section{Results}

\section{Case 1}

Proband 1 (Table 1) is now an 11-year-old girl. Her medical history started at 8 months of age, when she experienced severe seizures associated with marked hypocalcemia $(1.24 \mathrm{mmol} / \mathrm{l})$ due to primitive hypoparathyroidism $(0.66 \mathrm{pmol} / \mathrm{l})$. Treatment with $1-\alpha$ hydroxylated vitamin $\mathrm{D}$ was initiated and helped normalize the serum calcium level $(2.17 \mathrm{mmol} / \mathrm{l})$. However, when she was 5 years old, she developed nephrocalcinosis (calcium/creatinine $1.35 \mathrm{mmol} /$ mmol) and mild renal failure; the dose of $1-\alpha$ hydroxylated vitamin D was decreased and calcium supplementation was added. At age 6 years, dental enamel abnormalities were noticed and a severe episode of fatigue was observed. At age 7 years, plasma magnesium deficiency was detected. These various findings strongly suggested the involvement of a CASR gain-of-function mutation. The family history was negative for any similar clinical profiles (Fig. 2a).

Direct sequence analysis of PCR-amplified CASR exons identified a heterozygous mutation (c.2405A $\rightarrow$ T) in exon 7 leading to an amino acid substitution (p.N802I) in the protein. This change was not found in any of the 100 CASR gene alleles from 50 unrelated normal individuals. No other mutations were identified. 


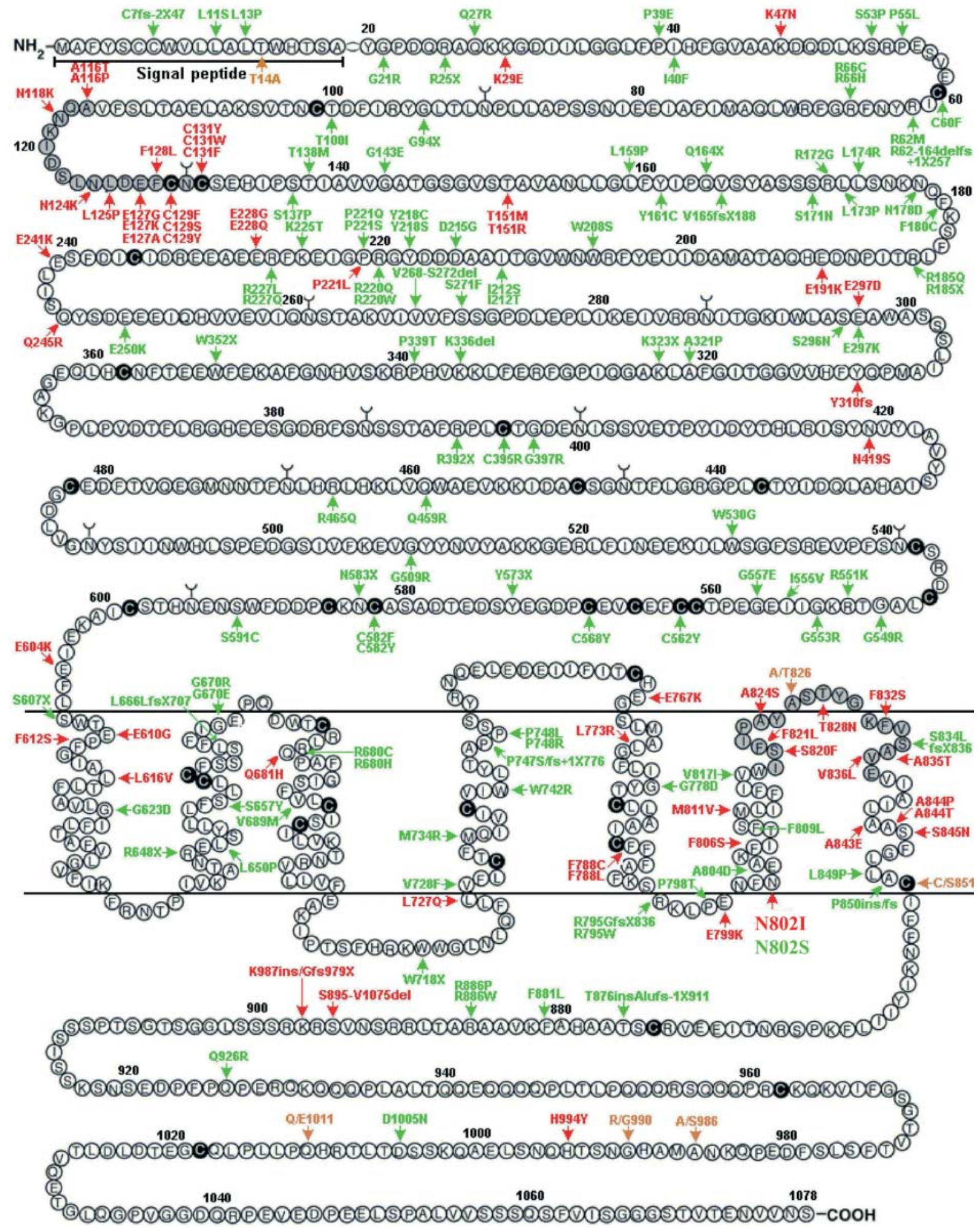

Figure 1 The human CASR amino acid sequence with the known mutations indicated (adapted from Hu J \& Spiegel AM. Structure and function of the human calcium-sensing receptor: insights from natural and engineered mutations and allosteric modulators. Journal of Cellular and Molecular Medicine 200711 908-922 and reproduced with permission). Naturally occurring hCASR-activating mutations and the p.N802I mutation are indicated in red, inactivating mutations are indicated in green and polymorphisms in orange. 
Table 1 Biochemical analyses at various ages in Proband 1 carrying the p.N802I mutation.

\begin{tabular}{lccccc}
\hline & $\begin{array}{c}\text { Serum calcium } \\
(\mathrm{mmol} / \mathrm{l}) \text { ref } \\
\text { Age }\end{array}$ & $\begin{array}{c}\text { PTH }(\mathrm{pmol} / \mathrm{l}) \text { ref } \\
(1.1-5.8)\end{array}$ & $\begin{array}{c}\text { Calcium/creatinine } \\
(\mathrm{mmol} / \mathrm{mmol}) \\
\text { ref }(<1)\end{array}$ & $\begin{array}{c}\text { Natremia }(\mathrm{mmol} / \mathrm{l}) \\
\text { ref }(136-145)\end{array}$ & $\begin{array}{c}\mathrm{Kaliemia}(\mathrm{mmol} / \mathrm{l}) \\
\text { ref }(3.2-5)\end{array}$ \\
\hline 8 months & 1.24 & 0.66 & 0.005 & - & - \\
5 years 2 months & 2.17 & 0.43 & - & 140 & 3.7 \\
6 years & 2.05 & 0.32 & - & - & - \\
6 years 6 months & 1.87 & - & - & - & - \\
7 years 2 months & 2.02 & 0.43 & 0.71 & 138 & 4 \\
7 years 9 months & 2.18 & 0.85 & 1.5 & & - \\
\hline
\end{tabular}

DNA samples from the other family members were not available, but the absence of a similar clinical picture in the family suggested that this CASR mutation occurred de novo in Proband 1.

\section{Case 2}

Proband 2 (Table 2), a 30-year-old woman, had been suffering from tiredness for a long time. A biochemical check-up showed a mild elevated serum calcium level (2.69 mmol/l) but an inappropriate high level of PTH (7.98 pmol/l). Her mother and sister were also tested: results for the mother were normal, whereas the sister showed a normal high serum calcium level (2.48 $\mathrm{mmol} / \mathrm{l})$, a high calciuria value $(7.75 \mathrm{mmol} /$ day $)$, and a very high level of PTH (13.1 pmol/l) (Table 2 and Fig. 2b).

Nucleotide sequencing identified a novel heterozygous mutation (c.2405A $\rightarrow \mathrm{G}$ ) in exon 7 leading to a p.N802S amino acid substitution in the protein. This change was not found in 100 CASR gene alleles from 50 unrelated normal individuals. No other mutations were identified. The mutation was also present in the affected sister but not in the asymptomatic mother, who had normal CASR sequences. DNA samples from the father were not available but the presence of the mutation in two daughters strongly suggests that the father was a carrier of the mutation.

\section{Functional analysis of WT and mutant receptors}

The responses of the mutant and WT receptors to extracellular calcium were assessed using a MAPK pathway trans-reporting system (Fig. 3). WT CASR cDNA was transiently expressed in Cos-7 cells: for the WT-CASR, the $\mathrm{EC}_{50}$ of $\mathrm{Ca}^{2+}$ was $2.22 \pm 0.16 \mathrm{mM}$ (mean \pm s.E.M.; $n=4$; Fig. 3a), and, as expected, there was no cellular response when WT-CASR was not stimulated (extracellular calcium at $0 \mathrm{mM}$ ); the activity progressively increased with increasing $\mathrm{Ca}^{2+}$ concentration to a plateau $\left(100 \%\right.$ activity) at $4 \mathrm{mM} \mathrm{Ca}^{2+}$ (Fig. 3a, bold line).

Most CASR with activating mutations show a leftward shift in their dose-response curve relative to that of the WT. The mutation p.E241K, already described by Christie et al. (13) and also detected in one of our patients suffering from hypocalcemia, was used as a reference (Fig. 3a, dotted line). Mutant p.N802I (Proband 1) showed a different profile: at $0 \mathrm{mM}$ $\mathrm{Ca}^{2+}$, it displayed $70 \%$ of the maximal WT activity, suggesting that the mutation had a constitutive activating effect even in the absence of extracellular calcium stimulation.

Furthermore, the activity of mutant p.N802I also increased up to $114 \%$ of the maximum WT activity at $4 \mathrm{mM} \mathrm{Ca}^{2+}$ concentration. Therefore, it was sensitive to $\mathrm{Ca}^{2+}$ concentration in addition to its constitutive activation.

To our knowledge, only one other CASR mutation has been described that causes constitutive activation: the p.A843E mutation in TMD7 (14). In order to compare p.N802I with p.A843E properly, we tested them side by side in our system. The p.A843E mutation shows a strong constitutive activation, but its response to extracellular calcium differs from that of the p.N802I mutation (Fig. 4). In the absence of $\mathrm{Ca}^{2+}$, p.A843E displays $150 \%$ of the maximal WT activity and this value is stable (around $155 \%$ ) at all $\mathrm{Ca}^{2+}$ concentrations. Thus, it is possible to say that, in addition to its constitutive activation, p.N802I seems to remain sensitive to $\mathrm{Ca}^{2+}$ concentration, which is not the case for p.A843E.

Mutant p.N802S (Proband 2) showed impaired CASR function, confirming the clinical diagnosis of FHH. The dose-response curve was right-shifted relative to the WT receptor, consistent with an inactivating mutation (Fig. 3a). (a)

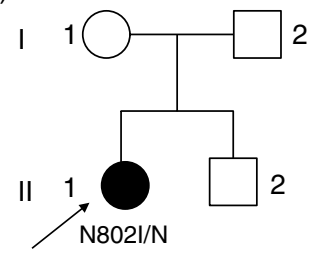

(b)

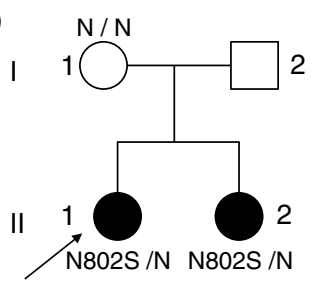

Figure 2 Pedigrees of the two families studied, (a) Case 1, (b) Case 2. The probands are indicated by an arrow. The genotypes were determined by mutation analysis. $\mathrm{N}$ corresponds to the normal allele. Clinical data are given in Materials and methods section. 
Table 2 Biochemical analyses of family members and of Proband 2 carrying the p.N802S mutation.

\begin{tabular}{lcccc}
\hline Patient & $\begin{array}{c}\text { Serum calcium (mmol/l) } \\
\text { ref }(2.10-2.55)\end{array}$ & $\begin{array}{c}\text { PTH } \\
(\mathrm{pmol} / \mathrm{l})\end{array}$ & $\begin{array}{c}\text { Urinary calcium (mmol/day) } \\
\text { ref }(1.1-5.8)\end{array}$ & $\begin{array}{c}\text { 25-OH Vit D (nmol/l) } \\
\text { ref }(>75)\end{array}$ \\
\hline Proband (II-1) & 2.69 & 7.98 & 4.05 & 36.5 \\
Mother (I-1) & 2.38 & 5 & 1.12 & - \\
Sister (II-2) & 2.48 & 13.09 & 7.75 & 34 \\
\hline
\end{tabular}

Treatment of CASR mutants with the calcilytic agent NPS-2143

To test whether the calcilytic agent NPS-2143 could reduce CASR mutant p.N802I activity at calcium concentrations within the physiological range, we stimulated cells with various extracellular calcium concentration in the presence or absence of $300 \mathrm{nM}$ NPS-2143 (Fig. 3b). In Cos-7 cells expressing WT CASR, NPS-2143 abolished the tested CASR activity, demonstrating that it is active in our system (dashed line). The same phenomenon was observed for p.N802S CASR, which already presented a weak level of activity (not shown). The CASR activity of the constitutively active mutant, p.N802I, was lower in the presence than in the absence of NPS-2143; however, NPS-2143 did not completely inhibit its activity, such that at all extracellular calcium concentrations the CASR mutant p.N802I activity was about half that of the maximum observed for the WT enzyme in the absence of NPS-2143.

\section{Discussion}

Two novel CASR mutations of the same amino acid (p.N802) lead to opposite symptoms. The heterozygous missense mutation p.N802I, a novel gain-of-function CASR mutation, causes hypercalciuric hypocalcemia whereas the heterozygous missense mutation p.N802S, an inactivating CASR mutation, results in mild hypercalcemia. This type of phenomenon has rarely been described for CASR and these observations suggest that this amino acid is central to ligand binding and/or receptor activation.

Other amino acid mutations of CASR have been reported to induce opposite effects: p. P221L is an activating mutation whereas p.P221Q and p.P221S inactivate CASR $(15,16,17,18)$; similarly, p.E297D is activating and p.E297K is inactivating $(4,19,20)$, and p.L173F is activating and p.L173P is inactivating $(21,22)$; all these mutations are located in the ECD. These amino acid positions are presumably located in regions involved in ligand binding $\left(\mathrm{Ca}^{2+}\right)$, as suggested by Silve et al. (20). In the TMD, the p.A843V mutation leads to CASR inhibition, whereas p.A843E leads to constitutive activation of the CASR, independent of calcium concentration and ECD structure. This mutation probably locks the TMD in an active conformation (14). The p.N802 mutations we describe here are localized at the beginning of the sixth TMD of CASR (Fig. 1) (23). This region appears to be a hot spot for gain-of-function mutations. Indeed, eight of the 71 known gain-of-function mutations $(11.3 \%)$ of CASR map within this region (which is only around $2.4 \%$ of the entire CASR protein), suggesting that this region has an important role in CASR activity.

A model of GPCR activation is that there is a dynamic equilibrium between two states of the GPCR: a conformation favoring $G$ protein coupling $\left(\mathrm{R}^{*}\right)$ and one that does not favor G protein coupling (24). Many naturally occurring activating missense mutations have
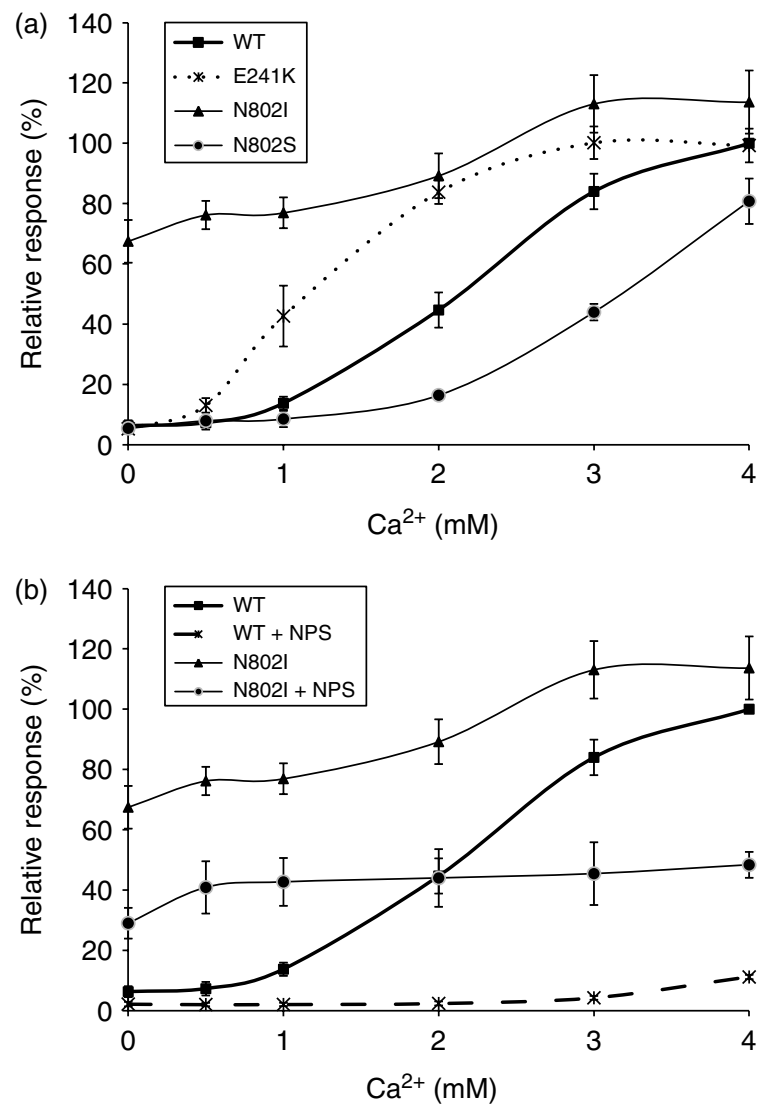

Figure 3 Extracellular calcium-evoked increases in MAPK activity in Cos cells transiently transfected with a MAPK trans-reporting system and wild-type (WT) or mutant p.N802I or p.N802S or p.E241K CASR cDNAs without (a) or with (b) 300 nM NPS-2143 treatment. Values reported are mean \pm S.E.M. of four experiments. All responses are normalized to the maximum response of WT human CASR. 


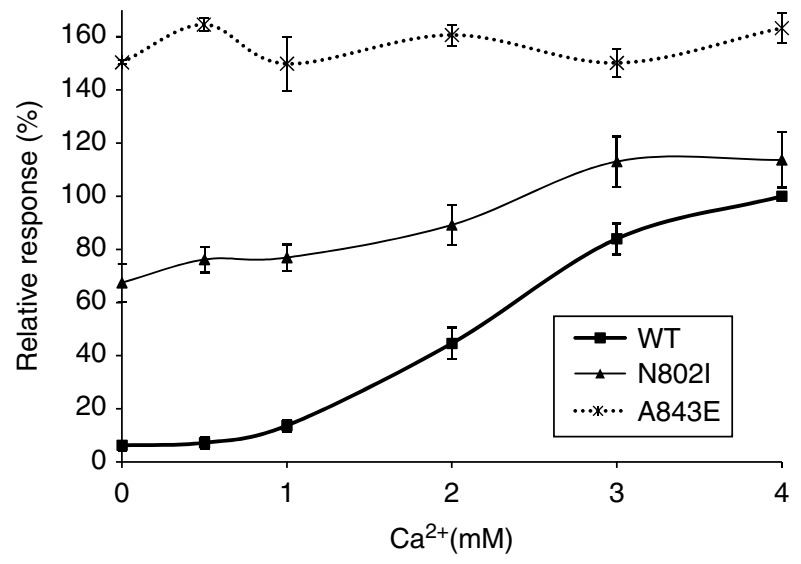

Figure 4 Extracellular calcium-evoked increases in MAPK activity in Cos cells transiently transfected with an MAPK trans-reporting system and wild-type (WT) or mutant p.N802I or p.A843E CASR cDNAs. Values reported are mean \pm s.E.M. of four experiments. All responses are normalized to the maximum response of WT human CASR.

been identified in various GPCRs in numerous diseases. Analysis of agonist-independent constitutive activating mutations led to the idea that mutation of these residues disrupts the normal inhibitory constraints and favors the formation of $\mathrm{R}^{*}$. Most such mutations map to TMD6, implicating this region in GPCR activation (see 25) (for review). In contrast, most activating CASR mutations result in increased sensitivity to $\mathrm{Ca}^{2+}$ rather than true constitutive activation. Of the 71 activating CASR mutations identified to date, 37 map in the ECD, a region known to be important for $\mathrm{Ca}^{2+}$ binding. Missense mutations of the ECD may therefore lead to inappropriate CASR activation by increasing the affinity for $\mathrm{Ca}^{2+}$. Similarly, the 30 mutations localized within the CASR TMD or extra/intracellular loops also exhibit enhanced sensitivity to $\mathrm{Ca}^{2+}$ rather than constitutive activation. To our knowledge, only two CASR mutations have been described that cause constitutive activation rather than enhanced $\mathrm{Ca}^{2+}$ sensitivity: the p.A843E mutation in TMD7 (14) and the p.N802I mutation we report here in TMD6. Our head-to-head comparison between these two constitutive mutations shows that while both of them present a very strong constitutive activation in the absence of $\mathrm{Ca}^{2+}(67$ and $150 \%$ for p.N802I and p.A843E respectively), their responses to extracellular calcium differ (Fig. 4). Only p.N802I seems to remain sensitive to $\mathrm{Ca}^{2+}$ concentration which is not the case for p.A843E.

The p.N802 residue is highly conserved in mammals (Pan troglodytes, Mus musculus, Rattus norvegicus, Canis lupus familiaris, and Bos taurus) and also in other animal species (Gallus gallus and Danio rerio). Interestingly, this amino acid is also conserved in other non-CASR GPCRs, including the human metabotropic glutamate receptors (mGluR), consistent with it being functionally important. We therefore suggest that p.N802I, without $\mathrm{Ca}^{2+}$ binding, disrupts the inhibitory constraints that prevent $G$ protein coupling. It is possible that the mutation affects side-chain packing in TMD6 or contacts with residues in other TM helices, for example p.A843. Such changes could alter the configuration of one or more intracellular loops in such a way that it favors $\mathrm{G}$ protein coupling. However, the structure of CASR has not been accurately determined, so these suggestions remain speculative.

We show that the p.N802I mutant is only partially sensitive to NPS-2143, an allosteric modulator of the CASR: in the presence of NPS-2143, the response of p.N802I CASR is lowered (to $40 \%$ from $67 \%$ of the WT value, in the absence of calcium) and it becomes insensitive to the calcium concentration but retains constitutive activity (around 40\%). This is unlike all other tested activating mutations: NPS-2143 decreases but does not abolish sensitivity to calcium (9). This may indirectly indicate that p.N802 is an important amino acid involved in the $\mathrm{G}$ protein signaling.

The phenotype of Proband 1 (p.N802I) was severe. She presented with symptoms from age 8 months and required treatment with 1- $\alpha$ hydroxylated vitamin $\mathrm{D}$ for marked hypocalcemia and had iatrogenic nephrocalcinosis by age 5 years. It proved difficult to normalize serum calcium level (Table 1). This clinical presentation is consistent with the corresponding mutant's response curve to calcium and the strength of its constitutive activation. While Bartter syndrome has been observed in $\mathrm{ADH}$ patients presenting strong activation mutations, such as p.A843E or p.L125P $(14,26)$, this syndrome has not been observed in our patient (normal natremia and kaliemia, Table 1). By contrast, the phenotype of Proband 2 (p.N802S) was very mild and she was diagnosed only when she was 30 years old. One should note the atypical presentation of $\mathrm{FHH}$ in this family, which could have been misdiagnosed as primary hyperparathyroidism if DNA testing and functional studies had not secured the diagnosis. Indeed, inappropriate high PTH level and normal calciuria to hypercalciuria are observed in the proband and in her sister. Similar observations have already been made in FHH families $(3,27,28)$. High PTH level could be explained by vitamin $\mathrm{D}$ deficiency, as vitamin $\mathrm{D}$ supplementation has been shown to reduce serum PTH levels to the normal range in FHH patients (29). Hypercalcemia with hypercalciuria has already been observed in a Swedish family presenting p.F881L mutation in CASR (28). Thereafter, several other mutations (p.T100I, p.L650P, p.V689M (27), p.Q926R, and p.D1005N (30)) have been associated with atypical 'FHH' presentations including hypercalciuria. One hypothesis could be that various biochemical phenotypes in FHH patients could be correlated with specific genotypes (17) and that mutations may not have the same impact on the distinct signaling pathways regulated by CASR (MAPK pathways activation vs PI-PLC for instance) and in different tissues 
(parathyroid glands vs cortical thick ascending limb). It could be interesting to test this hypothesis on a large panel of classical and atypical $\mathrm{FHH}$ patients.

These findings suggest that the sixth TMD, and specifically p.N802, have a major role in CASR activation. Our study illustrates the value of precise characterization of the activation profile of CASR mutants. This allows phenotype-genotype correlations, which may help select adequate treatment for the patient.

\section{Declaration of interest}

The authors declare that there is no conflict of interest that could be perceived as prejudicing the impartiality of the research reported.

\section{Funding}

This research did not receive any specific grant from any funding agency in the public, commercial, or not-for-profit sectors.

\section{References}

1 Brown EM, Gamba G, Riccardi D, Lombardi M, Butters R, Kifor O, Sun A, Hediger MA, Lytton J \& Hebert SC. Cloning and characterization of an extracellular $\mathrm{Ca}(2+)$-sensing receptor from bovine parathyroid. Nature 1993366 575-580. (doi:10.1038/366575a0)

2 Hendy GN, D’Souza-Li L, Yang B, Canaff L \& Cole DE. Mutations of the calcium-sensing receptor (CASR) in familial hypocalciuric hypercalcemia, neonatal severe hyperparathyroidism, and autosomal dominant hypocalcemia. Human Mutation $2000 \mathbf{1 6}$ 281-296. (doi:10.1002/1098-1004(200010)16:4<281::AIDHUMU1 > 3.0.CO;2-A)

3 Livadariu E, Auriemma RS, Rydlewski C, Vandeva S, Hamoir E, Burlacu MC, Maweja S, Thonnard AS, Betea D, Vassart G et al. Mutations of calcium-sensing receptor gene: two novel mutations and overview of impact on calcium homeostasis. European Journal of Endocrinology 2011165 353-358. (doi:10.1530/EJE11-0121)

4 Pollak MR, Brown EM, Chou YH, Hebert SC, Marx SJ, Steinmann B, Levi T, Seidman CE \& Seidman JG. Mutations in the human $\mathrm{Ca}(2+)$-sensing receptor gene cause familial hypocalciuric hypercalcemia and neonatal severe hyperparathyroidism. Cell 199375 1297-1303. (doi:10.1016/0092-8674 (93)90617-Y)

5 Pollak MR, Chou YH, Marx SJ, Steinmann B, Cole DE, Brandi ML, Papapoulos SE, Menko FH, Hendy GN \& Brown EM. Familial hypocalciuric hypercalcemia and neonatal severe hyperparathyroidism. Effects of mutant gene dosage on phenotype. Journal of Clinical Investigation 199493 1108-1112. (doi:10.1172/ JCI117062)

6 Baron J, Winer KK, Yanovski JA, Cunningham AW, Laue L, Zimmerman D \& Cutler GB. Mutations in the $\mathrm{Ca}(2+)$-sensing receptor gene cause autosomal dominant and sporadic hypoparathyroidism. Human Molecular Genetics 19965 601-606. (doi:10.1093/hmg/5.5.601)

7 Pearce SH, Williamson C, Kifor O, Bai M, Coulthard MG, Davies M, Lewis-Barned N, McCredie D, Powell H, Kendall-Taylor P et al. A familial syndrome of hypocalcemia with hypercalciuria due to mutations in the calcium-sensing receptor. New England Journal of Medicine 1996335 1115-1122. (doi:10.1056/NEJM199610 103351505)

8 Pidasheva S, D’Souza-Li L, Canaff L, Cole DE \& Hendy GN. CASRdb: calcium-sensing receptor locus-specific database for mutations causing familial (benign) hypocalciuric hypercalcemia, neonatal severe hyperparathyroidism, and autosomal dominant hypocalcemia. Human Mutation 200424 107-111. (doi:10.1002/humu. 20067)

$9 \mathrm{Hu}$ J, McLarnon SJ, Mora S, Jiang J, Thomas C, Jacobson KA \& Spiegel AM. A region in the seven-transmembrane domain of the human $\mathrm{Ca}^{2+}$ receptor critical for response to $\mathrm{Ca}^{2+}$. Journal of Biological Chemistry 2005280 5113-5120. (doi:10.1074/jbc. M413403200)

10 Al-Salameh A, Cetani F, Pardi E, Vulpoi C, Pierre P, de Calan L, Guyetant S, Jeunemaitre X \& Lecomte P. A novel mutation in the calcium-sensing receptor in a French family with familial hypocalciuric hypercalcaemia. European Journal of Endocrinology 2011165 359-363. (doi:10.1530/EJE-11-0141)

11 Lazarus S, Pretorius CJ, Khafagi F, Campion KL, Brennan SC, Conigrave AD, Brown EM \& Ward DT. A novel mutation of the primary protein kinase $\mathrm{C}$ phosphorylation site in the calcium-sensing receptor causes autosomal dominant hypocalcemia. European Journal of Endocrinology $2011 \mathbf{1 6 4} 429-435$. (doi:10.1530/EJE-10-0907)

12 Hendy GN, Minutti C, Canaff L, Pidasheva S, Yang B, Nouhi Z, Zimmerman D, Wei C \& Cole DE. Recurrent familial hypocalcemia due to germline mosaicism for an activating mutation of the calcium-sensing receptor gene. Journal of Clinical Endocrinology and Metabolism $2003 \mathbf{8 8} 3674-3681$. (doi:10.1210/jc.2003030409)

13 Christie P, Curley A, Nesbit MA, Harding B, Bowl M \& Thakker R. Characterization of 25 calcium-sensing receptor mutations in disorders of calcium homeostasis. Society for Endocrinology BES Endocrine Abstracts 2007 13: P1. http://www.endocrineabstracts. org/ea/0013/ea0013p1.htm

14 Zhao XM, Hauache O, Goldsmith PK, Collins R \& Spiegel AM. A missense mutation in the seventh transmembrane domain constitutively activates the human $\mathrm{Ca}^{2+}$ receptor. FEBS Letters 1999448 180-184. (doi:10.1016/S0014-5793(99)00368-3)

15 Conley YP, Finegold DN, Peters DG, Cook JS, Oppenheim DS \& Ferrell RE. Three novel activating mutations in the calciumsensing receptor responsible for autosomal dominant hypocalcemia. Molecular Genetic Metabolism 200071 591-598. (doi:10.1006/mgme.2000.3096)

16 Lienhardt A, Bai M, Lagarde JP, Rigaud M, Zhang Z, Jiang Y, Kottler ML, Brown EM \& Garabedian M. Activating mutations of the calcium-sensing receptor: management of hypocalcemia. Journal of Clinical Endocrinology and Metabolism 200186 5313-5323. (doi:10.1210/jc.86.11.5313)

17 Nissen PH, Christensen SE, Heickendorff L, Brixen K \& Mosekilde L. Molecular genetic analysis of the calcium sensing receptor gene in patients clinically suspected to have familial hypocalciuric hypercalcemia: phenotypic variation and mutation spectrum in a Danish population. Journal of Clinical Endocrinology and Metabolism 2007 92 4373-4379. (doi:10.1210/jc.2007-0322)

18 Pearce SH, Trump D, Wooding C, Besser GM, Chew SL, Grant DB, Heath DA, Hughes IA, Paterson CR, Whyte MP et al. Calciumsensing receptor mutations in familial benign hypercalcemia and neonatal hyperparathyroidism. Journal of Clinical Investigation 199596 2683-2692. (doi:10.1172/JCI118335)

19 Bai M, Quinn S, Trivedi S, Kifor O, Pearce SH, Pollak MR, Krapcho K, Hebert SC \& Brown EM. Expression and characterization of inactivating and activating mutations in the human $\mathrm{Ca}^{2+}$ o-sensing receptor. Journal of Biological Chemistry 1996271 19537-19545. (doi:10.1074/jbc.271.32.19537)

20 Silve C, Petrel C, Leroy C, Bruel H, Mallet E, Rognan D \& Ruat M. Delineating a $\mathrm{Ca}^{2+}$ binding pocket within the venus flytrap module of the human calcium-sensing receptor. Journal of Biological Chemistry 200545 37917-37923. (doi:10.1074/jbc. M506263200)

21 Felderbauer P, Hoffmann P, Klein W, Bulut K, Ansorge N, Epplen JT, Schmitz F \& Schmidt WE. Identification of a novel calcium-sensing receptor gene mutation causing familial hypocalciuric hypercalcemia by single-strand conformation polymorphism analysis. Experimental and Clinical Endocrinology E Diabetes 2005113 31-34. (doi:10.1055/s-2004-830523) 
22 Hannan FM, Nesbit MA, Zhang C, Cranston T, Curley AJ, Harding B, Fratter C, Rust N, Christie PT, Turner JJ et al. Identification of 70 calcium-sensing receptor mutations in hyperand hypo-calcaemic patients: evidence for clustering of extracellular domain mutations at calcium-binding sites. Human Molecular Genetics 201212 2768-2778. (doi:10.1093/hmg/ dds105)

$23 \mathrm{Hu} \mathrm{J} \mathrm{\&} \mathrm{Spiegel} \mathrm{AM.} \mathrm{Structure} \mathrm{and} \mathrm{function} \mathrm{of} \mathrm{the} \mathrm{human} \mathrm{calcium-}$ sensing receptor: insights from natural and engineered mutations and allosteric modulators. Journal of Cellular and Molecular Medicine 200711 908-922. (doi:10.1111/j.15824934.2007.00096.x)

24 Lefkowitz RJ. G protein-coupled receptor kinases. Cell $1993 \mathbf{7 4}$ 409-412. (doi:10.1016/0092-8674(93)80042-D)

25 Gether U. Uncovering molecular mechanisms involved in activation of G protein-coupled receptors. Endocrine Reviews 200021 90-113. (doi:10.1210/er.21.1.90)

26 Vargas-Poussou R, Huang C, Hulin P, Houillier P, Jeunemaître X, Paillard M, Planelles G, Déchaux M, Miller RT \& Antignac C. Functional characterization of a calcium-sensing receptor mutation in severe autosomal dominant hypocalcemia with a Bartter-like syndrome. Journal of the American Society of Nephrology 200213 2259-2266. (doi:10.1097/01.ASN.0000025781. $16723.68)$

27 Warner J, Epstein M, Sweet A, Singh D, Burgess J, Stranks S, Hill P, Perry-Keene D, Learoyd D, Robinson B et al. Genetic testing in familial isolated hyperparathyroidism: unexpected results and their implications. Journal of Medical Genetics 200441 155-160. (doi:10.1136/jmg.2003.016725)

28 Carling T, Szabo E, Bai M, Ridefelt P, Westin G, Gustavsson P, Trivedi S, Hellman P, Brown EM, Dahl N et al. Familial hypercalcemia and hypercalciuria caused by a novel mutation in the cytoplasmic tail of the calcium receptor. Journal of Clinical Endocrinology and Metabolism 200085 2042-2047. (doi:10.1210/jc.85.5.2042)

29 Zajickova K, Vrbikova J, Canaff L, Pawelek PD, Goltzman D \& Hendy GN. Identification and functional characterization of a novel mutation in the calcium-sensing receptor gene in familial hypocalciuric hypercalcemia: modulation of clinical severity by vitamin D status. Journal of Clinical Endocrinology and Metabolism 200792 2616-2623. (doi:10.1210/jc.2007-0123)

30 Rus R, Haag C, Bumke-Vogt C, Bähr V, Mayr B, Möhlig M, Schulze E, Frank-Raue K, Raue F \& Schöfl C. Novel inactivating mutations of the calcium-sensing receptor: the calcimimetic NPS $\mathrm{R}-568$ improves signal transduction of mutant receptors. Journal of Clinical Endocrinology and Metabolism 200893 4797-4803. (doi:10.1210/jc.2008-1076)

Received 17 August 2012

Revised version received 26 October 2012

Accepted 20 November 2012 